\title{
Branded content infantil
}

\section{Children's branded content}

Fecha | Publicación final: 01/01/2017

\section{Dr. Raúl RODRÍGUEZ-FERRÁNDIZ}

Universidad de Alicante. España. r.rodriguez@ua.es

Bajo la influencia del Branded Content. Efectos de los contenidos de marca en niños y jóvenes

Coordinadores: Rodrigo RON; Antón ÁLVAREZ y Patricia NÚÑEZ Madrid: ESIC, 2014.

205 páginas

ISBN: 978-84-7356-741-1

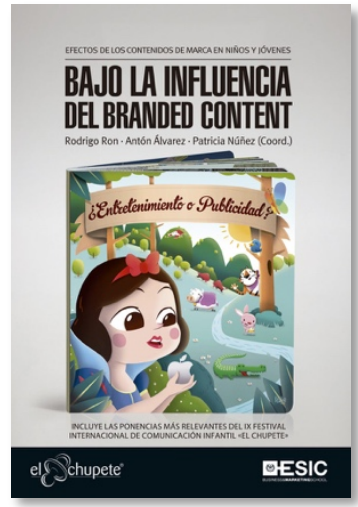

\section{Resumen}

Reseña del libro Bajo la influencia del branded content. Efectos de los contenidos de marca en niños y jóvenes.

\section{Palabras clave}

Contenidos de marca; infancia; adolescencia; marketing infantil.

\section{Abstract}

Review of the book Bajo la influencia del branded content. Efectos de los contenidos de marca en niños y jóvenes.

\section{Keywords}

Branded content; childhood; adolescence; children's marketing. 
Branded Content es un término en boga entre los profesionales y académicos dedicados a la comunicación publicitaria. Responde a la típica tendencia a la "hibridación" entre conceptos que parecerían a primera vista contradictorios, o incluso que han construido las oposiciones básicas que armaron nuestras discriminaciones genéricas, nuestros mapas conceptuales: todo lo sólido se desvanece en el aire, o al menos es arramblado por el torrente líquido que borra las fronteras. En el ámbito de la comunicación tenemos un ejemplo en Reality Show: acostumbrados a clasificar los programas televisivos entre los de ficción y los de no ficción, los reality shows hacen saltar el eje, porque provocan la espectacularización de los sucesos de vidas reales de una manera inédita, que no era propia ni de los documentales más estilizados ni de las ficciones cinematográficas o televisivas más verité.

Algo similar podríamos decir del Branded Content: acostumbrados a que la tele, la radio u otros medios masivos nos dieran por un lado contenidos de nuestro interés (series o seriales, films, informativos, documentales, programas educativos) y por otro interrumpieran esos contenidos con mensajes comerciales a menudo fastidiosos, supone un desafío encontrar contenidos que susciten nuestro interés y que a la vez sirvan a los intereses de una marca que es capaz de introducirse en ellos y fecundarlos de ideas, de historias, de experiencias (y no de eslóganes, jingles o banners).

Ahora bien, como casi todos los autores que colaboran en el volumen recuerdan, el Branded Content será un término novedoso, pero en absoluto es un fenómeno nuevo. De hecho, hoy podemos calificar así a muchas de las estrategias que emplearon los pioneros de la comunicación publicitaria desde los inicios de la era industrial. En aquellos tiempos de la prensa, incluso algo más tarde, con una radio primero y luego una televisión todavía en mantillas, el branded content era el modo habitual del proceder comunicativo al que llegaban naturalmente agencias de publicidad, marcas y medios comerciales: content y promotion no eran, como tampoco aspiran a serlo ahora conscientemente, entidades claras y distintas.

El volumen recoge las ponencias presentadas con motivo del IX Festival de Comunicación Infantil "EI Chupete", celebrado el 26 y 27 de junio de 2013. Como es habitual en las publicaciones de la editorial ESIC, hay un balance muy interesante entre aportaciones procedentes del ámbito profesional (anunciantes y medios) y del académico (docente e investigador), sin que se aprecie disonancia entre unas y otras. Los textos de profesionales de la comunicación están bien documentados y armados y aspiran a abordar el fenómeno del Branded Content sin limitarse a encarecer las bondades de su agencia o de su marca en ese terreno. Y los textos de profesores conjugan exposición amena de conocimientos de teoría y de historia de la publicidad con ejemplos muy bien traídos y analizados en general. Unos y otros están ilustrados, y cada ilustración cuenta con un pie que la contextualiza perfectamente. Y el libro concluye con algo que lo prolonga y lo enriquece transmedialmente: unos códigos Bidi enlazan con contenidos audiovisuales que hacen al caso (campañas publicitarias, acciones de comunicación, declaraciones de expertos, muy oportunas).

Las presentaciones y prólogos dan cuenta de la voluntad de aunar perspectivas diversas y del semillero que está en el origen del proyecto editorial: el Festival El Chupete, representado por su fundador y director (Rodrigo Ron) y por el famoso publicista y presidente del jurado de una de sus ediciones (Luis Casadevall), y el Departamento de Comunicación Audiovisual y Publicidad I de la UCM, representado por Raúl Eguizábal, su director, y reputado experto en historia de la publicidad.

Los catorce capítulos del volumen trazan un recorrido por los aspectos más relevantes del Branded Content, y en especial de aquel dedicado a un público infantil. Y lo hacen desde perspectivas complementarias. Unas son históricas y terminológicas (Antón Álvarez, Javier Regueira). Otras parten de experiencias en marcas concretas, aunque con la vocación de extrapolarse al sector del consumo o al modelo comunicativo (Roberto Herranz y Bezoya "Bebé a bordo"; Marisol Piñero y la revista Clan, Jaime Lobera y Campofrío "Cómicos", Carlos Bosch y Víctor Gutiérrez de Tena y Danone/Havas Media "Mis primeras veces;" Araceli Castelló y Cristina del Pino y Coca-Cola "La felicidad en cuatro minutos", "I+B. Ir más a los bares" y "Coca-Cola Music Experience"). Y otras ponen el foco en géneros, formatos o productos de las industrias culturales susceptibles de acoger contenidos de marca: la red y en especial YouTube (María Ferreras); las webseries (Victoria Tur y Jesús Segarra), los videojuegos ( $M^{a}$ Esther del Moral y Laura Fernández; Enrique Morales) y los juegos y juguetes (Esther Martínez, Miguel Ángel Nicolás y Marta Pacheco).

Las marcas que circulan por las páginas del volumen, más allá de las citadas, y el estudio de casos de branded content exitoso, son numerosos, y trazan un panorama muy amplio, nacional e internacional, de la estrategia: Red Bull y el Red Bull Stratos; Estrella Damm y las capañas veraniegas Mediterráneamente; Magnum y el videojuego Magnum Pleasure Hunt; Fanta y el videojuego Salvando la fuente; Turespaña y la webserie Fix You; Zara y el minidocumental Lucy Chadwick: A Selby Film for Zara; Citröen DS y la webserie Días de Shopping; El Corte Inglés y la webserie Probando, probando; los videojuegos y apps para 
smartphones Sims 2 Ikea Stuff, Domino's Pizza Hero; Nike Plus y Barclay's Waterslide Extreme, entre otros; los juegos en línea, las series en YouTube, las parques Legoland, los hoteles Lego de la marca danesa; las novelas (Alfaguara), la miniserie de televisión, el canal de YouTube, los filmes en DVD y los videojuegos (Nintendo), la revista (Panini) sobre las Monster High de Mattel...

Y todo ello no solo pensando en estimular el apetito consumista de más contenido, sino las ansias de hacer comunidad (compartir contenido) y las ansias de devenir autor, fabulador (de crear contenido propio) desde las plataformas y canales que las propias marcas habilitan para ello: quien queda atrapado por un contenido de marca parece más dispuesto no solo a consumirla y recomendarla, sino a ampliar el universo narrativo que diseña, a amueblarlo y a poblarlo de manera autónoma y gratificante.

Pero entonces, ¿qué ocurre con la publicidad tradicional? Hay una cuestión, a la vez ética, política y retórica (parece la tarea de un titán aristotélico: podríamos añadir incluso "poética") que el volumen no aborda. No era su objetivo, seguramente, pero sin duda deberíamos abordarla. Ajustar cuentas. Es la siguiente: ¿̇cómo es posible que los publicistas y los académicos que enseñamos publicidad nos avergoncemos hasta tal punto de esa palabra, que sustituimos indefectiblemente (pero abusivamente) por "comunicación"? ¿̇cómo es posible que asumamos tan acríticamente que la publicidad, de la que nos ocupamos, sea causa general de desinterés, hastío, reticencia, rechazo? ¿ qué se ha hecho mal y qué responsabilidad nos cabe? Y finalmente, ¿̇bastará el branded content para detener la sangría de desafección hacia el mensaje comercial, o es un parche momentáneo? Y si es esto último, ¿̇qué vendrá después, cuál será la coming attraction? 